\title{
Protected area effectiveness against land development in Spain
}

\author{
David Rodríguez-Rodríguez ${ }^{\text {a,b }}$, Javier Martínez-Vega ${ }^{\text {a }}$ \\ ${ }^{a}$ Institute of Economy, Geography and Demography, Spanish National Research Council (IEGD-CSIC), Associated Unit \\ GEOLAB. C/Albasanz, 26-28; 28037, Madrid, Spain. \\ ${ }^{b}$ University of Malaga, Andalucía Tech, European Topic Centre-Universidad of Malaga. Campus de Teatinos s/n, 29010 \\ Malaga, Spain.
}

Keywords: reserve network; performance; legal protection; management; land use-land cover; BACI design

Abstract: Land use-land cover (LULC) changes towards artificial covers are one of the main global threats to biodiversity conservation. In this comprehensive study, we tested a number of methodological and research hypotheses, and a new covariate control technique in order to address common protected area (PA) assessment issues and accurately assess whether different PA networks have had an effect at preventing development of artificial LULCs in Spain, a highly biodiverse country that has experienced massive socioeconomic transformations in the past two decades. We used digital census data for four PA networks designated between 1990 and 2000: Nature Reserves (NRs), Nature Parks (NPs), Sites of Community Importance (SCIs) and Special Protection Areas (SPAs). We analysed the effect of explanatory variables on the ecological effectiveness of protected polygons (PPs): Legislation stringency, cummulative legal designations, management, size, age and bio-physical characteristics. A multiple Before-After-ControlImpact (BACI) semi-experimental research design was used whereby artificial land cover increase (ALCI) and proportional artificial land cover increase (PALCI) results were compared inside and outside PAs, using $1 \mathrm{~km}$ and $5 \mathrm{~km}$ buffer areas surrounding PAs as controls. LULC data were retrieved from Corine Land Cover (CLC) 1990 and 2006 data. Results from three spatial-statistical models using progressively restrictive criteria to select control areas increasingly more accurate and similar to the assessed PPs were compared. PAs were a generally effective territorial policy to prevent land development in Spain. NRs were the most effective PA category, with no new artificial covers in the assessed period, although exact causality could not be attributed due to overlaps. SPAs were the least effective category, with worse ALCI data than their control areas. Legal protection was effective against land development, which was influenced by most biophysical variables. However, cumulative legal designations and PA management did not seem to influence land development. The spatial-statistical technique used to make cases and control environmentally similar did not produce consistent outcomes and should be refined.

\section{Introduction}

Habitat destruction and degradation are the primary causes of biodiversity loss in terrestrial and freshwater ecosystems (Joppa et al., 2008; Piekielek et al., 2012; WWF, 2016). They result from increasingly intensive LULC changes to meet rising food, commodity, energy, transport and housing demands (Smith et al., 2016). Among all LULC changes towards intensive uses, land development can arguably be considered the most concerning one from an environmental sustainability perspective because it can (and often does) cause permanent and irreversible destruction or degradation of natural and semi-natural habitats through impacts such as vegetation clearing, soil sealing, fragmentation or isolation (McKinney et al., 2002; Jiménez et al., 2005; EEA, 2011; Martínez-Fernández et al., 2015).

PAs are the main global policy for the long-term conservation of biodiversity and associated ecosystem services (Dudley et al., 2008; Gaston et al., 2008; Venter et al., 2014). Thus, preserving natural or semi-natural LULCs of high biodiversity value should be considered a paramount factor when assessing PA effectiveness (Gaston et al., 2008; Joppa et al., 2008; Nagendra, 2008). Some studies on the effectiveness of PA sets or networks to prevent conversion of natural LULCs have been conducted in tropical areas (Andam et al., 2008; Joppa et al., 2008; Pfeifer et al., 2012; Carranza et al., 2014; Spracklen et al., 2015; López-Rodríguez and Rosado, 2017) and in data-richer, temperate areas (Gaston et al., 2006; Araújo et al., 2007; Mallinis et al., 2014; Martínez-Fernández et al., 2015; Fiorini et al., 
2017). Although some of these studies have used sound semi-experimental designs to ascertain causality (Addison, 2011), few of them have discriminated the effect of legal protection and management effort in PA effectiveness related to LULC change.

Accurate attribution of PA effects faces a number of challenges (Schreckenberg et al., 2010; Addison, 2011; Ferraro and Hanauer, 2015). Firstly, partial or total overlap between different designation categories is common and makes it difficult to discriminate legal protection effects on official PA boundaries [Iojă et al., 2010, Foster et al., 2014; Stortini et al., 2015). Rodríguez-Rodríguez et al. (2016a) proposed a spatial 'protected polygon' (PP) approach that differentiates overlapping and non-overlapping PPs within official PA boundaries for more accurate analysis of legal effects. Secondly, PA boundaries are not static in time and, as conservation theory, resources and practice evolve, so is expected PA design in terms of shape, size or connectivity (Pressey et al., 2007; Araújo et al., 2011). Assigning PA effects with changing boundaries has therefore clear implications regarding result precision. Thirdly, selecting adequate control sites for pre-defined samples such as PAs remains an active research subject (Mas, 2005; Andam et al., 2008; Spracklen et al., 2015). Overlaps with PAs or other types of sectoral protection outside target PAs are also a common issue affecting control 'unprotected' areas (Spracklen et al., 2015). Some authors have tried to reduce control-case overlap problems by restricting buffer distances from PA boundaries, thus reducing the probability of overlap with neighbouring PAs (Pfeifer et al., 2012) or by extracting some other existing protected zones from the analysis (Andam et al., 2008; Spracklen et al., 2015). Additionally, PA effectiveness studies comparing LULC changes inside PAs and in ad hoc adjacent buffers outside PAs are not considered accurate enough, as buffers can have environmental or socioeconomic characteristics that are very different from those inside PAs so as to affect LULC changes, making comparisons inappropriate and results, biased (Mas, 2005; Andam et al., 2008). Different methods to mimic experimental studies by creating environmentally similar control sites to cases have been proposed: buffer areas with the same proportion of some categorical, uncorrelated variables (Mas, 2005); selection of adjacent, equal-area inner and outer zones (Spracklen et al., 2015); or more complex covariate matching methods (Andam et al., 2008). Although all these techniques control for the most common confounding factors affecting LULC, none of these studies claims to avoid all overt or hidden bias, as diverse unconsidered environmental and socioeconomic variables at different scales may influence multi-factorial variables such as LULC changes (Andam et al., 2008).

In densely populated places like Europe, human competition for land with biodiversity is intense (EEA, 2011). Artificial land cover increase is the dominant LULC change (EEA, 2015a), which seriously threatens European biodiversity (Davis et al., 2014). By the year 2000, the Mediterranean Basin was among the two global biodiversity hotspots with the greatest urban area and that area was forecasted to increase by $160 \%$ by 2030 (Seto et al., 2012). In Spain, a Euro-Mediterranean country affected by both regional trends, massive transport, residential and tourist infrastructure development in the past two decades has caused huge LULC changes towards artificial covers across the country, especially along the coast and in peri-urban areas (Jiménez et al., 2012; Alfonso et al., 2016). As a result of such trends, $99 \%$ of Spanish land is located within $7.6 \mathrm{~km}, 6.4 \mathrm{~km}$ and $5.2 \mathrm{~km}$ from a built-up area, transport corridor and impervious surface, respectively (Torres et al., 2016). Those changes peaked around 2007 , as soon after that year the housing bubble burst and subsequent economic and financial crisis markedly reduced new infrastructure, industrial or residential developments in the country García, 2010; FernándezTabales and Cruz, 2013). Spain is also a highly biodiverse country (Médail and Quézel, 1999; Williams et al., 2000; Araújo et al., 2007) which makes it especially important to assess and control the effects of land development on Spanish biodiversity. To respond to such sustainability challenge, substantial legislative effort has been made to designate PAs under different categories, which currently cover nearly $28 \%$ of the Spanish terrestrial territory (Múgica et al., 2014), although management effort, including monitoring and assessment, still needs considerable improvement in many PAs (Rodríguez-Rodríguez et al., 2015).

In this study, we used complete digital census PA data in Spain to: a) verify some methodological hypotheses to enhance accuracy of PA effectiveness assessments; b) test a number of research hypotheses related to the effectiveness of PAs as a public policy to prevent land development in Spain; and c) test a simple spatial-statistical technique for selecting adequate control areas and making more valid comparisons in PA effectiveness assessments.

\section{Materials and methods}

\subsection{Study area}

Spain covers most of the Iberian Peninsula, in southwestern Europe, plus two archipelagos: Balearic Islands and Canary Islands. The five PA categories assessed here were selected because they have clear legal, nominal and managerial characteristics across the whole country. Administrative competencies for PA designation and management correspond to the 19 regional governments, except for the overall coordination of the network of National Parks which is a national government's competency (Spanish Government, 2007; Spanish Government, 2014). Fig. 1 shows the spatial coverage of the PA categories assessed in this study according to their selection criteria. 


\subsection{Data collection and pre-processing}

Official digital boundaries of five PA networks representing most terrestrial protected area in Spain as well as a continuum in terms of legislation stringency were retrieved from the Spanish Ministry for Environment's digital repository updated by December 2014 (MAGRAMA, 2015): Nature Reserves $(\mathrm{N}=141)$, National Parks $(\mathrm{N}=10)$, Nature Parks $(\mathrm{N}=141)$, Special Areas of Conservation (SACs)/Sites of Community Importance (SCIs; N=1451) and Special Protection Areas (SPAs; $\mathrm{N}=636$ ). Only PAs that had not been, to our knowledge, reclassified or enlarged since their original designation dates were selected in order to provide precise results in time. We added national parks' peripheral protection zones to their respective national park area, as they confer legal protection against LULC changes (Spanish Government, 2014) and would thus make inadequate controls.

All GIS layers except SCIs' and SPAs' included each PA's designation date. For SCIs and SPAs, we joined the "Natura 2000 Access Database" including each site's proposal confirmation (for SCIs) and

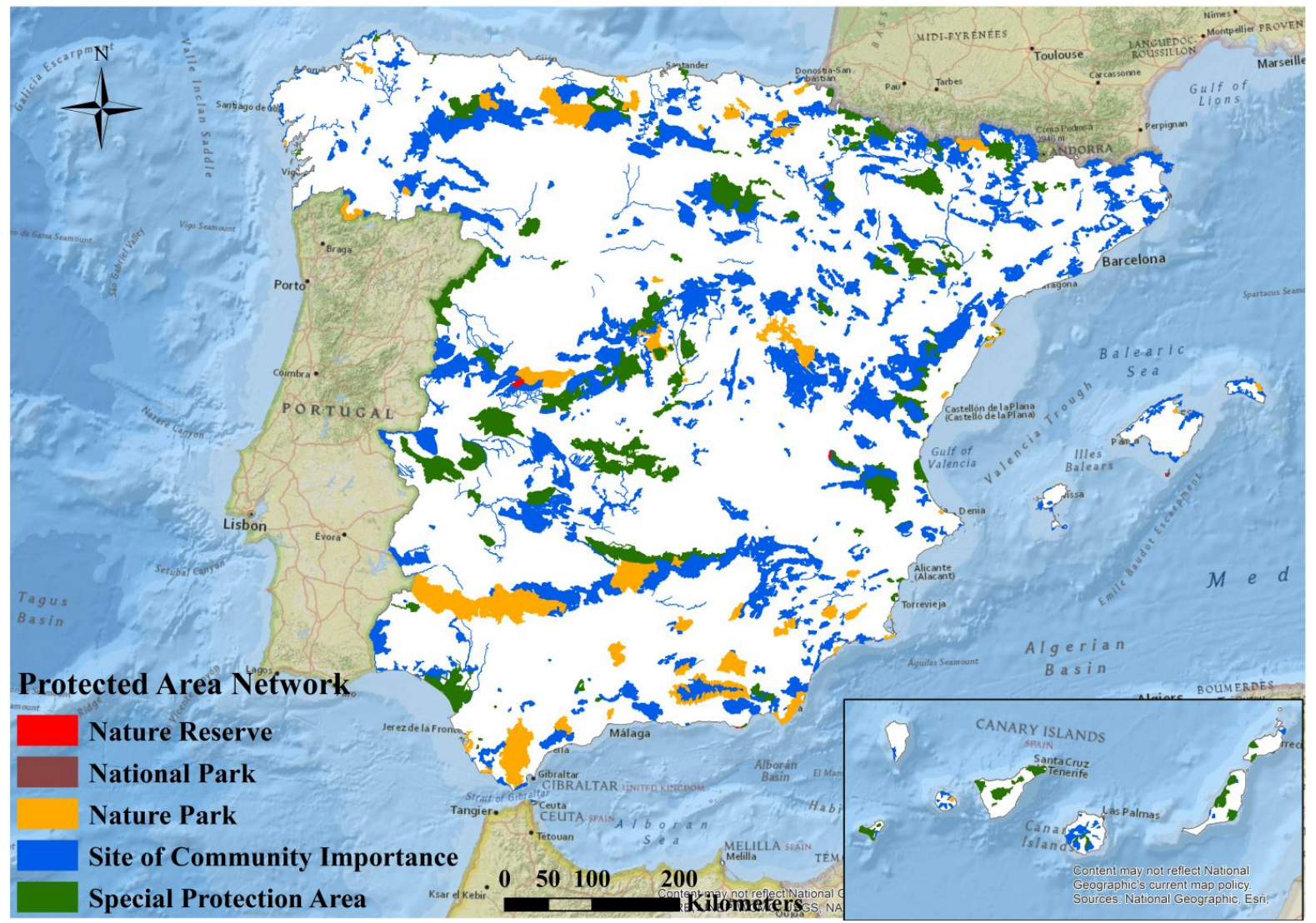

Fig. 1. Coverage of the Spanish protected area networks assessed in this study

designation dates (EEA, 2015b) to the original SCI and SPA layers. We considered SCIs' proposal dates as designation dates, as legal restrictions regarding LULC changes generally apply since the site is proposed for inclusion in national SCI proposal lists prior to submission for approval by the European Commission (European Communities, 2000). Only terrestrial PAs equal to or bigger than 100ha were selected $(\mathrm{N}=1,874$ PAs) due to the coarse resolution of CLC data (minimum mapping unit of 25ha). The five PA layers were unioned in a single PA layer, extracting PPs with and without overlaps with other PA designation categories (e.g. National Park and SPA). Only PPs equal to or bigger than 100 ha were selected because of CLC's broad resolution and because many of the smaller polygons were boundary alignment errors between the original PA layers. Previous PA spatial analyses have used this PP approach (Foster et al., 2014; RodríguezRodríguez et al., 2016a, 2016b) as it provides an ecologically meaningful, more accurate picture of protection than official PA boundaries that may include overlapping and non-overlapping, managed and unmanaged areas, thus likely confounding effects. Each overlapping PP was assigned to one of the PA networks according to the oldest designation category firstly 
assigned to it, as that was the date when at least legal protection of the enclosed land started.

A multiple BACI research design where the 'Impact' was PP designation was used to determine PA effectiveness, as suggested for causality attribution studies (Smith et al., 2002; Nagendra, 2008; Addison, 2011). In order to maximize accuracy in the attribution of effects, we unioned the PA layer with the satellite images that were used by photo-interpreters to produce CLC-1990 for Spain, whose dates were used as our 'Before' or baseline $\left(\mathrm{t}_{1}\right)$ data. Two hundred and sixtytwo partially overlapping satellite images covering the whole Spanish land territory were provided by the Spanish official body in charge of CLC photointerpretation: TRAGSATEC Ltd. We resolved overlaps between images with different dates by assigning them the most modern dates, which are the ones most likely used by photo-interpreters, as information on the exact dates of used CLC-1990 images could not be retrieved. We compared the level-5 (subsequently aggregated to level-3 for comparison with CLC-2006) CLC-1990 LULC data (IGN, 2016) ('Before'; average scene date of 1987) with the CLC-2006 data (IGN, 2016) as our 'After' (average scene date of July of 2005), for all PAs belonging to the five PA networks that were designated between the $27^{\text {th }}$ of June of 1984 (date of the first CLC1990 image) up to the $1^{\text {st }}$ of August of 2000. That way, we made sure that possible LULC changes inside PPs consistently occurred after legal protection and that the analysed period included at least three years of protection before the first CLC-2006 image (June of 2003). We detected that a notable amount of CLC class 1 area (most conspicuously, many existing transport infrastructures by 2006) did not appear in the official CLC-2006 version (IGN, 2016), so we accounted for this and created a new CLC-2006 class 1 layer that included all CLC-1990 class 1 covers plus those new class 1 covers in CLC-2006, thus assuming some excess of artificial areas around 2006 given that some of those 'added' artificial areas from CLC-1990, such as some mineral extraction sites and dump sites could have been reverted to semi-natural covers in that period (Jiménez, 2010; Martínez-Fernández et al., 2015). 'Controls' were produced by creating $1 \mathrm{~km}$ and $5 \mathrm{~km}$-buffer areas around each PP and assigning them that PP's network category. The result of that selection process was 1,075 PPs, which comprised all officially digitally recorded PP data from the five PA networks under those selection criteria (i.e. PP census data). National Parks could not be assessed as they were nearly entirely eliminated during the PP selection process (only one PP of that category remained). They had been mostly designated before or after our study period (1984-2000) and those that did not, had mostly been previously allocated a different PA category. The final protected area analysed reached $105,530 \mathrm{~km}^{2}$, or roughly $64 \%$ of the total terrestrial protected area of Spain by March of 2015. Legal stringency and management of the remainder four PA categories are summarised in Table 1.

Table 1

Legal and managerial characteristics of the four protected area networks assessed

\begin{tabular}{llllll}
\hline & Regulations & Stringency & PA type & Management & $\begin{array}{l}\text { IUCN } \\
\text { Management } \\
\text { Category }\end{array}$ \\
\hline Nature Reserves & Regional law & High & Reserve & Yes & Ia \& Ib \\
Nature Parks & Regional law & Medium & Multiple-use & Yes & V \\
$\begin{array}{l}\text { Sites of } \\
\text { Community }\end{array}$ & $\begin{array}{l}\text { Regional decree } \\
\text { (from European } \\
\text { Importance }\end{array}$ & Medium & Multiple-use & No & IV \\
$\begin{array}{l}\text { Special Protection } \\
\text { Areas }\end{array}$ & $\begin{array}{l}\text { Regional decree } \\
\text { (from European } \\
\text { Directive) }\end{array}$ & Medium & Multiple-use & No & IV \\
\hline
\end{tabular}

${ }^{1}$ Based on Atauri et al., 2008

We considered 'artificial areas' the following environmentally unsustainable level 2 CLC artificial subclasses: 1.1, 1.2 and 1.3: urban fabric; industrial, commercial and transport units; and mine, dump and construction sites. CLC subclass 1.4 (artificial, nonagricultural, vegetated areas) was not included because it comprises a large proportion of unsealed green areas, so they were considered a more sustainable and reversible artificial LULC (McKinney, 2002).

We used two complementary indicators on PA effectiveness at preventing artificial LULC increase:
ALCI and PALCI. ALCI was defined as the artificial area increase in all PPs (or buffers) of each PA network, in percentage:

$$
\operatorname{ALCI} x=\sum\left(\frac{\operatorname{ART} x(\mathrm{t} 2)-\operatorname{ART} x(\mathrm{t} 1)}{\operatorname{ART} x(\mathrm{t} 1)}\right) \times 10^{2}
$$

where ART $x_{(t 1)}$ is the sum of artificial areas in PP or buffer network $x$ around 1987 (in ha) and ART $x_{(\mathrm{t} 2)}$, is that sum around 2006. PALCI was defined as the 
proportional increase in artificial LULCs in each PP or buffer network, in percentage:

$$
\operatorname{PALCIx}=\sum\left(\frac{\operatorname{ARTx}(\mathrm{t} 2)-\operatorname{ART} \mathrm{x}(\mathrm{t} 1)}{\operatorname{AREAx}}\right) \times 10^{2}
$$

where $\mathrm{ART} x_{(\mathrm{t} 1)}$ and $\mathrm{ART} x_{(\mathrm{t} 2)}$ are the same as defined above and AREAx is the total area of the PP or buffer network $x$. All calculations were made using Arc-GIS v.10.2 in the ETRS-89 UTM projection.

\subsection{Models used to test the effect of PAs}

In order to discriminate the effects of legal protection and management and attribute those effects more validly, three PA effectiveness models of increasing degree of accuracy were created by progressively restricting cases and control areas according to their legal and bio-physical characteristics (Fig. 2)

\subsection{1. $\quad$ Model 0}

Entire PPs and $1 \mathrm{~km}$ and $5 \mathrm{~km}$-buffers were used to compute ALCI and PALCI. Only the assessed PP's area was excluded from buffer areas when it overlapped with them.

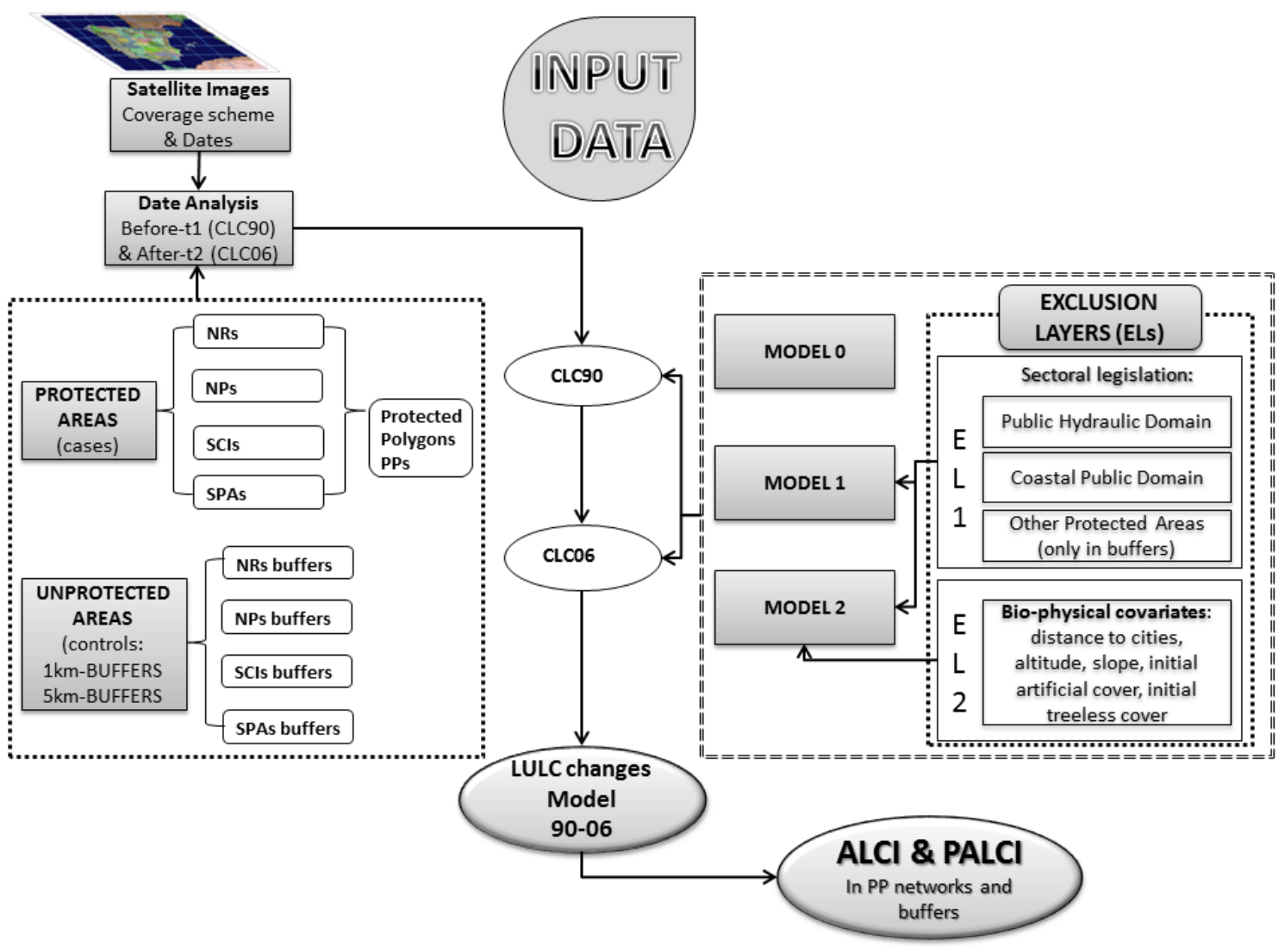

Fig. 2. Conceptual outline of the study

\subsection{2. $\quad$ Model 1}

Areas where permanent constructions are generally prohibited or severely restricted by diverse territorial legislation were excluded from the analysed PP area and buffer areas. All existing PAs designated before 2007 (Spanish Government, 1989; MAGRAMA, 2015), areas included in the public coastal domain (Spanish Government, 1988) and areas belonging to the public hydraulic domain (Spanish Government, 1985; Spanish Government, 2001; IGN, 2012) were used to produce the 'exclusion layer 1' (EL1) for buffer areas, as complete and consistent digital information for these layers for the whole country could be retrieved. EL1 for PPs only included public coastal domain areas and public hydraulic domain areas. EL1 was extracted to Model 0's PP, $1 \mathrm{~km}$ and $5 \mathrm{~km}$ buffer areas and ALCI and PALCI were computed on the remaining areas. Full details on 
how EL1 was produced can be found in Supplementary material S1.

\subsection{3. $\quad$ Model 2}

Areas that were bio-physically unrepresentative of each PP network were additionally excluded from Model 1's PP and buffer areas. For creating the 'exclusion layer' for Model 2 (EL2; Supplementary material S1), we analysed the environmental characteristics of each PP network according to seven bio-physical covariates that are thought to influence LULC change: 'altitude' ( Mas 2005; Pfeifer et al., 2012); 'slope' (Jiménez et al., 2005; Mas 2005); 'distance to main cities' (Mas 2005; Andam et al., 2008; Pfeifer et al., 2012); 'distance to main transport infrastructures' (Mas 2005; Andam et al., 2008; Pfeifer et al., 2012); 'distance to the coastline' (Jiménez et al., 2005; Pfeifer et al., 2012; Dias et al., 2013); 'degree of initial artificial land cover' (Jiménez, 2009; Martínez-Fernández et al., 2015); and 'degree of initial treeless cover' (Joppa et al., 2008; Sims 2014; Spracklen et al., 2015). Spearman rank-order correlation analyses were performed on Model 0's PPs to select only those covariates related to the dependent variable (PALCI) after checking data normality. Each of the five bio-physical covariate layers that significantly correlated with PALCI ('distance to main cities', 'altitude', 'slope', initial degree of artificial cover' and initial degree of treeless cover') was intersected with each PP network layer and with their respective $1 \mathrm{~km}$ and $5 \mathrm{~km}$ buffer areas, and unrepresentative values for each covariate and PA network were computed. Then, the five 'unrepresentative range' covariate layers were merged in a single EL2 layer and unrepresentative areas for all of them were extracted from Model 1's PP's and two buffers' layers (Supplementary material S1). Next, ALCI and PALCI were computed. A bio-physical Similarity Index was produced for each PP category and buffer zone by summing the absolute differences of the five covariate median values between PPs and both buffer areas $(1 \mathrm{~km}$ and $5 \mathrm{~km})$ :

$$
\operatorname{SIx}=\sum|\operatorname{Cypp}(\mathrm{x})-\operatorname{CyB} 1 \mathrm{k}(\mathrm{x})|
$$

where $\mathrm{C} y_{\mathrm{pp}}$ is the value of covariate $y$ of PPs in network $x$ and $C y_{\mathrm{B} 1 \mathrm{k}}$ is the value of covariate $y$ of $1 \mathrm{~km}$ buffer areas in network $x$ (equally, for $5 \mathrm{~km}$ buffers).

\subsection{Hypotheses tested}

The methodological and research hypotheses that were tested are summarised in Table 2 . The specific data comparisons used to test these hypotheses can be consulted in Supplementary material S2.

Research hypothesis verification results were classified in a qualitative probability scale (Table 3 ).

\section{Results}

\subsection{Bio-physical analysis of cases and controls}

- Methodological hypothesis 1: Proximal PA buffers $(1 \mathrm{~km})$ can be considered environmentally similar to their PAs. This hypothesis is largely unsupported by evidence. The Similarity Index ranged from 46 for SPAs to 637 for NRs in Model 0. All covariate values were very different between NRs and their $1 \mathrm{~km}$ surrounding buffers. For the remaining PA categories, covariate values were noticeably different with few exceptions. The covariate that consistently differed most for all PA categories (from 1.5 times to 4.5 times) was the 'initial degree of treeless cover' (Supplementary material S3).

- Methodological hypothesis 2: Proximal PA buffers $(1 \mathrm{~km})$ can be considered more environmentally similar to their PAs than distant buffers $(5 \mathrm{~km})$. This hypothesis is largely unsupported by evidence. SCIs and SPAs were more bio-physically similar to their $1 \mathrm{~km}$-buffers than to their $5 \mathrm{~km}$-buffers in Model 0, according to the SI. However, NRs and NPs were more bio-physically similar to their $5 \mathrm{~km}$ buffers than to their $1 \mathrm{~km}$ buffers (Supplementary material S3).

- Methodological hypothesis 3: PAs are designated in places bio-physically less prone to development than controls. This hypothesis is largely supported by evidence. All PA categories were closer to main cities than their $5 \mathrm{~km}$ controls: from over $0.5 \mathrm{~km}$ closer for SPAs to over $14 \mathrm{~km}$ closer for NRs on average. However, all PA categories except NRs were, in general, originally less prone to development than their controls for the remaining four covariates (except 'altitude' for SCIs, which was slightly lower than that of their $5 \mathrm{~km}$ controls). Differences between cases and controls were especially stark for the 'initial degree of treeless cover'. All controls had much higher values of that covariate than their cases (Supplementary material S3).

- Methodological hypothesis 4: The initial set of covariates influences land development. This hypothesis is largely supported by evidence. Six of the ten initial covariates were shown to influence PALCI in the Spanish PA networks that were considered: 'distance to main cities' $\left(r_{s(1073)}=\right.$ $0.160 ; p<0.00)$, 'altitude' $\left(r_{s(1073)}=-0.161 ; p<\right.$ $0.00)$, 'slope' $\left(r_{s(1073)}=-0.087 ; p<0.004\right)$, 'initial degree of artificial cover' $\left(r_{s(1073)}=0.356 ; p<\right.$ $0.000)$, 'initial degree of treeless cover' $\left(r_{s(1073)}=\right.$ $0.087 ; p=0.004)$, and PP's size $\left(r_{s(1073)}=0.076 ; p<\right.$ 0.012). Unexpectedly, 'distance to the coastline' and 'distance to main transport infrastructures' were not significantly correlated with PALCI for the complete set of PPs. However, when the 
Table 2

Methodological and research hypotheses tested, and supporting references

MH: Methodological hypothesis; RH: Research hypothesis

\begin{tabular}{|c|c|c|}
\hline $\begin{array}{l}\text { Hypothesis } \\
\text { type }\end{array}$ & Hypothesis & References \\
\hline MH1 & $\begin{array}{l}\text { Proximal buffers can be considered environmentally } \\
\text { similar to their PAs }\end{array}$ & $\begin{array}{l}\text { Oudin et al 2008; Rodríguez-Rodríguez and } \\
\text { Martínez-Vega, in press }\end{array}$ \\
\hline MH2 & $\begin{array}{l}\text { Proximal buffers }(1 \mathrm{~km}) \text { can be considered more } \\
\text { environmentally similar to their PAs than distant buffers } \\
(5 \mathrm{~km})\end{array}$ & $\begin{array}{l}\text { Oudin et al 2008; Rodríguez-Rodríguez and } \\
\text { Martínez-Vega, in press }\end{array}$ \\
\hline MH3 & $\begin{array}{l}\text { PAs are designated in places bio-physically less prone to } \\
\text { development than controls }\end{array}$ & $\begin{array}{l}\text { Mas 2005; Andam et al 2008; Gaston et al } \\
\text { 2008; Spracklen et al } 2015\end{array}$ \\
\hline MH4 & $\begin{array}{l}\text { The initial set of covariates ('cummulative legal } \\
\text { designations', 'PP's size', 'PP's age', 'distance to main } \\
\text { cities', 'distance to the coast, 'distance to main transport } \\
\text { infrastructures', 'altitude', 'slope', 'initial degree of } \\
\text { artificial cover' and 'initial degree of treeless cover') } \\
\text { influences land development }\end{array}$ & $\begin{array}{l}\text { Jiménez et al 2005; Mas 2005; Andam et al } \\
\text { 2008; McDonald et al 2008; Jiménez, 2009; } \\
\text { Araújo et al 2011; Pfeifer et al 2012; Dias et al } \\
\text { 2013; Spracklen et al 2015; Martínez-Fernández } \\
\text { et al 2015; Rodríguez-Rodríguez and Martínez- } \\
\text { Vega, in press }\end{array}$ \\
\hline MH5 & $\begin{array}{l}\text { Applying a spatial-statistical covariate control technique } \\
\text { makes cases and controls more environmentally similar }\end{array}$ & $\begin{array}{c}\text { Mas 2005; Rodríguez-Rodríguez and } \\
\text { Martínez-Vega, in press }\end{array}$ \\
\hline RH1 & PAs are effective to prevent land development & $\begin{array}{c}\text { Mallinis et al 2014; Martínez-Fernández et al } \\
\text { 2015; Rodríguez-Rodríguez and Martínez-Vega, } \\
\text { in press }\end{array}$ \\
\hline RH2 & Legal protection prevents land development & $\begin{array}{l}\text { Martínez-Fernández et al 2015; Rodríguez- } \\
\text { Rodríguez and Martínez-Vega, in press }\end{array}$ \\
\hline RH3 & $\begin{array}{l}\text { Legal stringency is effective at preventing land } \\
\text { development }\end{array}$ & $\begin{array}{l}\text { Seiferling et al 2012; Linardi et al 2013; } \\
\text { Terra et al., 2014; Martínez-Fernández et al } 2015\end{array}$ \\
\hline RH4 & $\begin{array}{l}\text { Additional legal protection further prevents land } \\
\text { development in PAs }\end{array}$ & Rodríguez-Rodríguez et al 2016 \\
\hline RH5 & $\begin{array}{l}\text { Management adds to legal protection to prevent land } \\
\text { development }\end{array}$ & $\begin{array}{c}\text { Hockings et al 2006; Dudley et al 2008; } \\
\text { Rodríguez-Rodríguez and Martínez-Vega, in } \\
\text { press }\end{array}$ \\
\hline RH6 & $\begin{array}{l}\text { Additional sectoral legislation further prevents land } \\
\text { development in PAs }\end{array}$ & $\begin{array}{c}\text { Andam et al 2008; Rodríguez-Rodríguez and } \\
\text { Martínez-Vega, in press }\end{array}$ \\
\hline RH7 & $\begin{array}{l}\text { Additional sectoral legislation confers protection to } \\
\text { controls against land development }\end{array}$ & $\begin{array}{c}\text { Andam et al 2008; Rodríguez-Rodríguez and } \\
\text { Martínez-Vega, in press }\end{array}$ \\
\hline RH8 & $\begin{array}{l}\text { The main uses of new artificial land covers inside PAs } \\
\text { are residential }\end{array}$ & $\begin{array}{l}\text { Rodríguez-Rodríguez, 2008; Radeloff et al } \\
\qquad 2010\end{array}$ \\
\hline RH9 & $\begin{array}{l}\text { The main uses of new artificial land covers in the } \\
\text { vicinity of PAs are residential }\end{array}$ & $\begin{array}{l}\text { Rodríguez-Rodríguez, 2008; Radeloff et al } \\
\qquad 2010\end{array}$ \\
\hline RH10 & New artificial covers tend to concentrate in the & Radeloff et al 2010 \\
\hline
\end{tabular}

Mas 2005; Andam et al 2008; Gaston et al 2008; Spracklen et al 2015; Rodríguez-Rodríguez and Martínez-Vega, in press

Table 3.

Hypothesis verification categories

\begin{tabular}{llc}
\hline Hypothesis verification category & \multicolumn{1}{c}{ Explanation } & Certainty \\
\hline Strongly supported/ unsupported & $\begin{array}{l}\text { The hypothesis is met/not met for all items without exceptions; the } \\
\text { three models show consistent results for all PAs and PA categories }\end{array}$ & High \\
Largely supported/ unsupported & $\begin{array}{l}\text { The hypothesis is met/not met for most items with one or few } \\
\text { exceptions; the hypothesis is met/ not met for all items but overlaps } \\
\text { introduce some confusion }\end{array}$ & Moderate \\
\hline
\end{tabular}


complete PP sample was reduced according to distance thresholds, correlations became significant for distances greater than $25 \mathrm{~km}$ from the coastline $\left(r_{s(283)}=-0.116 ; p=0.05\right)$ and distances smaller than $100 \mathrm{~km}$ from main highways and railways $\left(r_{s(553)}=-\right.$ $0.085 ; p=0.04)$.

- Methodological hypothesis 5: Applying a spatialstatistical covariate control technique makes cases and controls more environmentally similar. This hypothesis is largely unsupported by evidence. The covariate control technique used made cases and controls more environmentally similar for NPs and SPAs for most covariates in Model 2. Nevertheless, SCI cases and controls became more environmentally dissimilar after applying the technique (Supplementary material S3).

\subsection{PA effectiveness on land development}

Relative values of land development in PAs in 2006 for Model 0 ranged between $0 \%$ and $1.5 \%$ of PPs' network areas. In $1 \mathrm{~km}$-buffers, it ranged between $2.9 \%$ to $4.4 \%$ of buffer network areas and in $5 \mathrm{~km}$-buffers, from $2.4 \%$ to $4.6 \%$ (Fig. 2).

Table 3 shows the main descriptive statistics on land development for the complete set of PPs and controls by model. Table 4 shows the same statistics for the subset of non-overlapping PPs and controls by model.

- Research hypothesis 1: PAs are effective to prevent land development This hypothesis is largely supported by evidence. PALCI was smaller in PPs than in both buffer areas for all PA categories and models, for the whole set of PPs and the sub-set of non-overlapping PPs. Exceptions regarding ALCI occurred for SPAs in the whole set of PPs in every model and for all PPs in Model 2. Regarding the non-overlapping sub-set of PPs, exceptions to smaller ALCI occurred for all PPs and NPs in Models 0 and 1 and for SPAs in Model 2.

- $\quad$ Research hypothesis 2: Legal protection prevents land development. This hypothesis is largely supported by evidence. ALCI and PALCI values were consistently smaller for non-overlapping SCIs and SPAs than for their control areas in every model, with the exception of ALCI for Model 2 SPAs.

- Research hypothesis 3: Legal stringency is effective at preventing land development. This hypothesis is largely supported by evidence. ALCI and PALCI values for the complete set of NRs were consistently smaller than those for NPs, although category overlaps introduce some confusion.

- Research hypothesis 4: Additional legal protection further prevents land development in Pas. This hypothesis is largely unsupported by evidence. Unexpectedly, ALCI and PALCI values were not consistently smaller in the complete set of PPs regarding the non-overlapping sub-set. Additionally, the 'number of designation categories' was not correlated with PALCI for the complete set of PPs in Model 0.

- Research hypothesis 5: Management adds to legal protection to prevent land development. This hypothesis is largely unsupported by evidence. ALCI values were consistently smaller for both managed PP categories in the complete set of PPs. However, PALCI values were not. Additionally, non-overlapping NPs consistently experienced much more ALCI and PALCI than non-overlapping SCIs and SPAs.

- Research hypothesis 6: Additional sectoral legislation further prevents land development in Pas. This hypothesis is largely supported by evidence. ALCI values were smaller in Model 0 than in Model 1for all PPs and categories in both sets of PPs, the only exception being nonoverlapping SCIs, whereas PALCI values remained similar between models in both sets of PPs. 


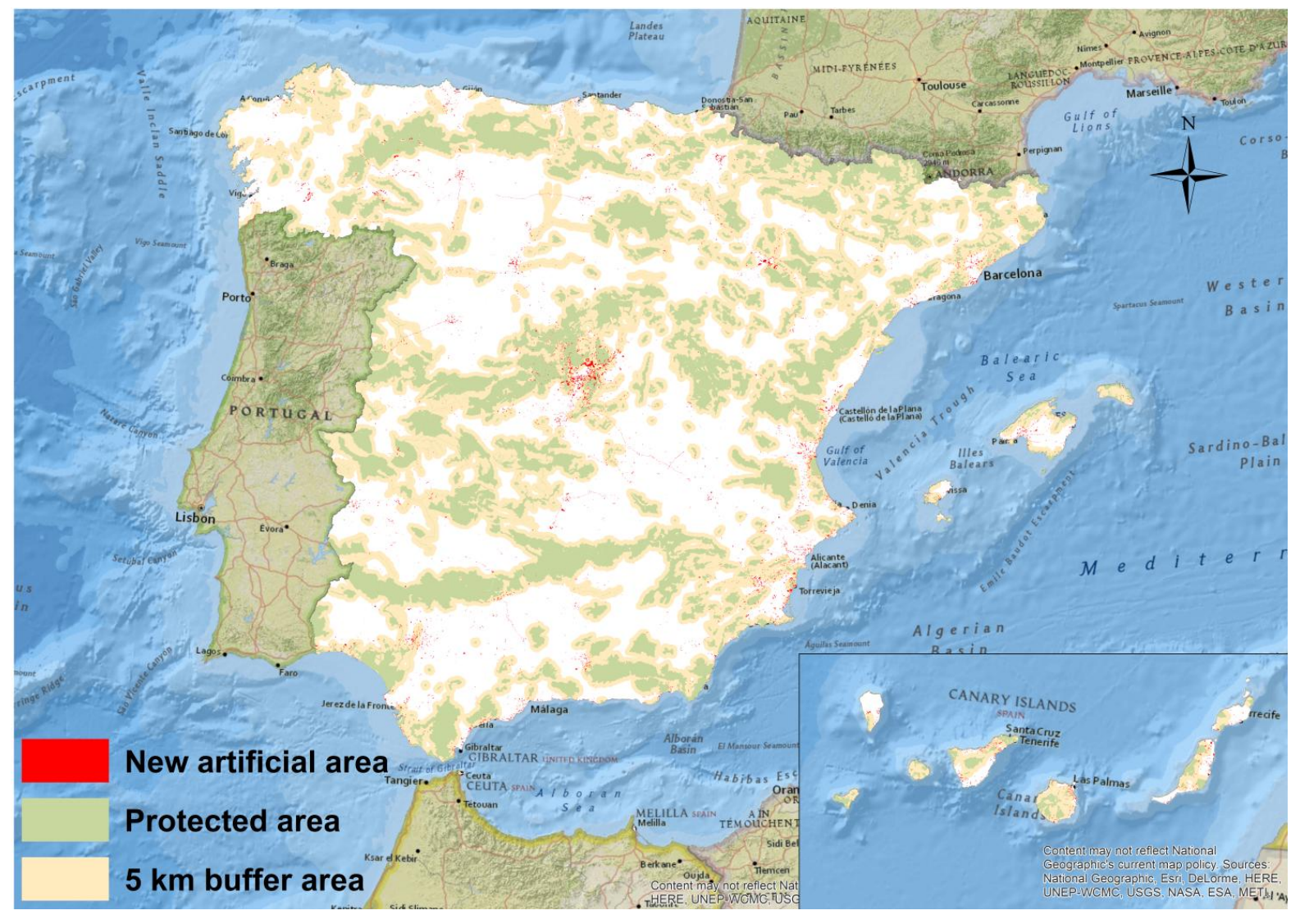

Fig. 3. New artificial area in Spanish protected areas, in five kilometre buffer areas and in the remainder of the territory in the 1987-2006 period. 
Table 3.

Descriptive statistics on land development by protected area network, buffer network and model in the complete set of protected polygons

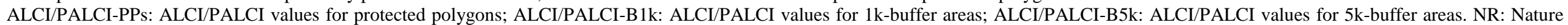
Reserve; NP: Nature Park; SCI: Site of Community Importance; SPA: Special Protection Area

\begin{tabular}{|c|c|c|c|c|c|c|c|c|c|c|c|c|}
\hline \multicolumn{13}{|c|}{ MODEL 0} \\
\hline PA network & ALCI-PPs & PALCI-PPs & Area (ha) & $\begin{array}{c}\text { New artificial } \\
\text { area (ha) }\end{array}$ & ALCI-B1k & PALCI-B1k & Area (ha) & $\begin{array}{l}\text { New artificial } \\
\text { area (ha) }\end{array}$ & ALCI-B5k & PALCI-B5k & Area (ha) & $\begin{array}{c}\text { New artificial } \\
\text { area (ha) }\end{array}$ \\
\hline NRs & & 0.00 & 9,957 & 0 & 88.25 & 1.44 & 3,636 & 52 & 60.71 & 0.92 & 24,637 & 226 \\
\hline NPs & 27.75 & 0.10 & $1,660,899$ & 1,725 & 44.52 & 1.34 & 391,521 & 5,245 & 48.10 & 1.46 & $1,789,410$ & 26,179 \\
\hline SCIs & 30.14 & 0.05 & $6,448,061$ & 3,526 & 34.35 & 0.68 & $3,914,868$ & 26,647 & 39.92 & 0.76 & $14,745,190$ & 111,805 \\
\hline SPAs & 66.85 & 0.19 & $2,433,049$ & 4,686 & 60.66 & 1.27 & 800,197 & 10,164 & 63.07 & 1.35 & $3,544,330$ & 47,942 \\
\hline All PPs & 39.86 & 0.09 & $10,553,087$ & 9,937 & 39.70 & 0.81 & $5,000,040$ & 40,615 & 42.87 & 0.85 & $17,948,400$ & 152,38 \\
\hline
\end{tabular}

\begin{tabular}{|c|c|c|c|c|c|c|c|c|c|c|c|c|}
\hline PA network & ALCI- PPs & PALCI-PPs & Area (ha) & $\begin{array}{c}\text { New artificial } \\
\text { area (ha) }\end{array}$ & ALCI- B1k & PALCI-B1k & Area (ha) & $\begin{array}{c}\text { New artificial } \\
\text { area (ha) }\end{array}$ & ALCI- B5k & PALCI-B5k & Area (ha) & $\begin{array}{c}\text { New artificial } \\
\text { area (ha) }\end{array}$ \\
\hline NRs & & 0.00 & 9,758 & $\overline{0}$ & 98.30 & 1.56 & 2,329 & 36 & 71.79 & 1.15 & 18,124 & 208 \\
\hline NPs & 28.49 & 0.11 & $1,611,740$ & 1,696 & 44.89 & 1.61 & 305,815 & 4,935 & 49.39 & 1.68 & $1,479,130$ & 24,801 \\
\hline SCIs & 30.43 & 0.05 & $6,257,040$ & 3,266 & 35.19 & 0.75 & $3,203,600$ & 23,896 & 41.37 & 0.82 & $12,662,710$ & 103,851 \\
\hline SPAs & 68.01 & 0.19 & $2,362,190$ & 4,509 & 67.11 & 1.48 & 642,142 & 9,496 & 66.76 & 1.53 & $2,969,730$ & 45,429 \\
\hline All PPs & 40.61 & 0.09 & $10,241,900$ & 9,471 & 41.17 & 0.91 & $4,074,693$ & 36,97 & 44.68 & 0.93 & $15,342,420$ & 142,587 \\
\hline
\end{tabular}

\begin{tabular}{|c|c|c|c|c|c|c|c|c|c|c|c|c|}
\hline PA network & ALCI- PPs & PALCI-PPs & Area (ha) & $\begin{array}{c}\text { New artificial } \\
\text { area (ha) }\end{array}$ & ALCI- B1k & PALCI-B1k & Area (ha) & $\begin{array}{l}\text { New artificial } \\
\text { area (ha) }\end{array}$ & ALCI- B5k & PALCI-B5k & Area (ha) & $\begin{array}{c}\text { New artificial } \\
\text { area (ha) }\end{array}$ \\
\hline NPs & 9.83 & 0.02 & $1,363,920$ & 279 & 13.84 & 0.18 & 78,942 & 141 & 22.08 & 0.30 & 269,444 & 814 \\
\hline SCIs & 30.41 & 0.06 & $4,810,760$ & 2,654 & 39.93 & 0.30 & $1,734,580$ & 5,147 & 49.61 & 0.45 & $6,306,840$ & 28,169 \\
\hline SPAs & 70.28 & 0.20 & $2,179,040$ & 4,268 & 33.86 & 0.25 & 486,25 & 1,219 & 69.24 & 0.76 & $1,929,480$ & 14,622 \\
\hline All PPs & 40.81 & 0.09 & $8,363,628$ & 7,201 & 37.41 & 0.29 & $2,274,380$ & 6,491 & 51.94 & 0.50 & $7,888,190$ & 39,071 \\
\hline
\end{tabular}


Table 4.

Descriptive statistics on land development by protected area network, buffer network and model in the non-overlapping set of protected polygons

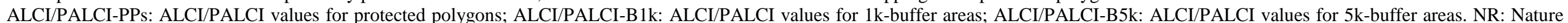
Reserve; NP: Nature Park; SCI: Site of Community Importance; SPA: Special Protection Area

\begin{tabular}{|c|c|c|c|c|c|c|c|c|c|c|c|c|}
\hline \multicolumn{13}{|c|}{ MODEL 0} \\
\hline $\begin{array}{r}\text { PA } \\
\text { network }\end{array}$ & $\begin{array}{l}\text { ALCI- } \\
\text { PPs }\end{array}$ & $\begin{array}{l}\text { PALCI } \\
\text {-PPs }\end{array}$ & Area (ha) & $\begin{array}{c}\text { New } \\
\text { artificial area } \\
\text { (ha) }\end{array}$ & $\begin{array}{l}\text { ALCI- } \\
\text { B1k }\end{array}$ & $\begin{array}{l}\text { PALCI- } \\
\text { B1k }\end{array}$ & Area (ha) & $\begin{array}{c}\text { New } \\
\text { artificial area } \\
\text { (ha) }\end{array}$ & $\begin{array}{l}\text { ALCI- } \\
\text { B5k }\end{array}$ & $\begin{array}{l}\text { PALCI- } \\
5 \mathrm{k}\end{array}$ & Area (ha) & $\begin{array}{c}\text { New } \\
\text { artificial area } \\
\text { (ha) }\end{array}$ \\
\hline NPs & 161.25 & 0.91 & 16,243 & 147 & 80.86 & 1.17 & 14,635 & 171 & 53.85 & 1.62 & 82,044 & 1,327 \\
\hline SCIs & 37.04 & 0.06 & $2,752,357$ & 1,615 & 37.94 & 0.66 & $2,241,195$ & 14,904 & 42.83 & 0.75 & $9,339,430$ & 69,693 \\
\hline SPAs & 45.30 & 0.15 & 319,409 & 475 & 47.99 & 0.80 & 142,620 & 1,143 & 56.60 & 0.97 & 753,624 & 7,320 \\
\hline All PPs & 40.67 & 0.07 & $3,088,009$ & 2,237 & 38.76 & 0.68 & $2,392,613$ & 16,200 & 43.57 & 0.77 & $10,012,390$ & 76,664 \\
\hline \multicolumn{13}{|c|}{ MODEL 1} \\
\hline $\begin{array}{r}\text { PA } \\
\text { network }\end{array}$ & $\begin{array}{l}\text { ALCI- } \\
\text { PPs }\end{array}$ & $\begin{array}{l}\text { PALCI } \\
\text {-PPs }\end{array}$ & Area (ha) & $\begin{array}{c}\text { New } \\
\text { artificial area } \\
\text { (ha) }\end{array}$ & $\begin{array}{l}\text { ALCI- } \\
\text { B1k }\end{array}$ & $\begin{array}{l}\text { PALCI- } \\
\text { B1k }\end{array}$ & Area (ha) & $\begin{array}{c}\text { New } \\
\text { artificial area } \\
\text { (ha) }\end{array}$ & $\begin{array}{l}\text { ALCI- } \\
\text { B5k }\end{array}$ & $\begin{array}{l}\text { PALCI- } \\
5 \mathrm{k}\end{array}$ & Area (ha) & $\begin{array}{c}\text { New } \\
\text { artificial area } \\
\text { (ha) }\end{array}$ \\
\hline NPs & 166.74 & 0.91 & 16,145 & 147 & 87.71 & 1.21 & 14,083 & 171 & 55.45 & 1.67 & 77,172 & 1,290 \\
\hline SCIs & 36.77 & 0.05 & $2,668,290$ & 1,449 & 38.42 & 0.71 & $1,926,240$ & 13,609 & 44.43 & 0.80 & $8,204,650$ & 65,469 \\
\hline SPAs & 45.94 & 0.15 & 307,131 & 456 & 50.77 & 0.88 & 125,132 & 1,095 & 61.74 & 1.04 & 659,218 & 6,871 \\
\hline All PPs & 40.86 & 0.07 & $2,991,560$ & 2,053 & 39.35 & 0.72 & $2,060,500$ & 14,856 & 45.32 & 0.82 & $8,792,510$ & 71,999 \\
\hline \multicolumn{13}{|c|}{ MODEL 2} \\
\hline $\begin{array}{r}\text { PA } \\
\text { network }\end{array}$ & $\begin{array}{l}\text { ALCI- } \\
\text { PPs }\end{array}$ & $\begin{array}{l}\text { PALCI } \\
\text {-PPs }\end{array}$ & Area (ha) & $\begin{array}{c}\text { New } \\
\text { artificial area } \\
\text { (ha) } \\
\end{array}$ & $\begin{array}{l}\text { ALCI- } \\
\text { B1k }\end{array}$ & $\begin{array}{l}\text { PALCI- } \\
\text { B1k }\end{array}$ & Area (ha) & $\begin{array}{c}\text { New } \\
\text { artificial area } \\
\text { (ha) }\end{array}$ & $\begin{array}{l}\text { ALCI- } \\
\text { B5k }\end{array}$ & $\begin{array}{l}\text { PALCI- } \\
5 \mathrm{k}\end{array}$ & Area (ha) & $\begin{array}{c}\text { New } \\
\text { artificial area } \\
\text { (ha) } \\
\end{array}$ \\
\hline SCIs & 34.00 & 0.05 & $2,082,209$ & 985 & 46.38 & 0.34 & 990,063 & 3,329 & 57.95 & 0.48 & $4,011,180$ & 19,400 \\
\hline SPAs & 57.89 & 0.14 & 276,547 & 380 & 29.30 & 0.42 & 99,863 & 424 & 41.86 & 0.58 & 413,814 & 2,409 \\
\hline All PPs & 38.42 & 0.06 & $2,363,569$ & 1,366 & 43.52 & 0.34 & $1,088,735$ & 3,754 & 55.71 & 0.49 & $4,388,120$ & 21,718 \\
\hline
\end{tabular}


- Research hypothesis 7: Additional sectoral legislation confers protection to buffers against land development. This hypothesis is strongly supported by evidence. All buffers and buffer categories increased their ALCI and PALCI values in Model 1 with regard to Model 0 in both sets of PPs.

- Research hypothesis 8: The main uses of new artificial land covers inside PAs are residential.
This hypothesis is largely supported by evidence. The main new artificial uses in Spanish PAs between 1987 and 2006 were still residential in absolute terms, although they proportionally increased less than other artificial uses and reduced their proportion among all artificial land uses (Table 5).

Table 5

New artificial land uses in Spanish protected areas and $1 \mathrm{~km}$ and 5km-buffer areas in the 1987-2006 period. PP: Protected polygon. B1K: 1km-buffer area. B5k: 5km-buffer area

\begin{tabular}{|c|c|c|c|c|c|c|c|c|}
\hline & & \multicolumn{2}{|c|}{1987} & \multicolumn{2}{|c|}{2006} & \multicolumn{3}{|c|}{$1987-2006$} \\
\hline & & ha & $\%$ & ha & $\%$ & $\begin{array}{l}\text { Increase } \\
\text { (ha) }\end{array}$ & $\begin{array}{l}\text { Increase } \\
(\%)\end{array}$ & $\begin{array}{l}\text { Difference } \\
(\%)\end{array}$ \\
\hline \multirow[t]{6}{*}{ PPs } & Residential areas & 15,893 & 64.36 & 19,778 & 57.13 & 3,885 & 24.44 & -7.23 \\
\hline & Industrial areas & 1,185 & 4.80 & 2,379 & 6.87 & 1,194 & 100.76 & 2.07 \\
\hline & Infrastructures & 1,321 & 5.35 & 2,040 & 5.89 & 719 & 54.43 & 0.54 \\
\hline & Mine and dump sites & 5,333 & 21.60 & 8,934 & 25.80 & 3,601 & 67.52 & 4.20 \\
\hline & Construction sites & 963 & 3.90 & 1,492 & 4.31 & 529 & 54.93 & 0.41 \\
\hline & Total artificial & 24,695 & 100 & 34,623 & 100 & 9,928 & 40.20 & 0.00 \\
\hline \multirow[t]{6}{*}{ B1k } & Residential areas & 82,071 & 77.30 & 103,917 & 70.08 & 21,846 & 26.62 & -7.22 \\
\hline & Industrial areas & 7,888 & 7.43 & 14,039 & 9.47 & 6,151 & 77.98 & 2.04 \\
\hline & Infrastructures & 6,691 & 6.30 & 9,127 & 6.16 & 2,436 & 36.41 & -0.14 \\
\hline & Mine and dump sites & 7,940 & 7.48 & 13,475 & 9.09 & 5,535 & 69.71 & 1.61 \\
\hline & Construction sites & 1,576 & 1.48 & 7,716 & 5.20 & 6,140 & 389.59 & 3.72 \\
\hline & Total artificial & 106,166 & 100 & 148,274 & 100 & 42,108 & 39.66 & 0.01 \\
\hline \multirow[t]{6}{*}{ B5k } & Residential areas & 305,256 & 74.29 & 395,260 & 66.20 & 90,004 & 29.48 & -8.09 \\
\hline & Industrial areas & 38,370 & 9.34 & 76,803 & 12.86 & 38,433 & 100.16 & 3.52 \\
\hline & Infrastructures & 30,168 & 7.34 & 39,242 & 6.57 & 9,074 & 30.08 & -0.77 \\
\hline & Mine and dump sites & 28,693 & 6.98 & 47,768 & 8.00 & 19,075 & 66.48 & 1.02 \\
\hline & Construction sites & 8,403 & 2.05 & 37,972 & 6.37 & 29,569 & 351.89 & 4.32 \\
\hline & Total artificial & 410,890 & 100 & 597,045 & 100 & 186,155 & 45.31 & 0.00 \\
\hline
\end{tabular}

- Research hypothesis 9: The main uses of new artificial land covers in the vicinity of PAs are residential. This hypothesis is largely supported by evidence. The main artificial uses in both control areas were still residential, but they proportionally increased less than other artificial land uses and reduced their proportion among all artificial LULCs in the analysed period (Table 5).

- $\quad$ Research hypothesis 10: New artificial covers tend to concentrate in the immediate vicinity of PAs. This hypothesis is largely unsupported by evidence. ALCI and PALCI were greater in the 5km-buffers than in the $1 \mathrm{~km}$-buffers in every model for all PPs and categories in both sets of buffer areas, except for NR's buffers and non-overlapping NP's buffers (only for ALCI) in which the contrary occurred.

- Research hypothesis 11: Bio-physical factors contribute to PA protection against land development. This hypothesis is largely supported by evidence. Initially, NRs were the PA category bio-physically least likely to become artificial: they were the most distant to main cities and had the lowest initial degree of treeless covers on average (Table 6). Accordingly, it was the category that 
experienced less ALCI. In contrast, NPs were the category with the highest probability of becoming artificial: they were the category nearest to main cities and with the highest initial degree of artificial cover on average. However, NPs only had the greatest ALCI and PALCI values in the nonoverlapping set of PPs. When comparing PP categories with their controls (1km-buffers) according to the SI, most bio-physical variables made NRs more prone to development than their controls (less distance to cities, altitude and slope), but they experienced no ALCI or PALCI. The remaining PA categories were bio-physically less prone to development and experienced less ALCI and PALCI than their controls, except ALCI for the complete set of SPAs and the non-overlapping set of NPs and SPAs (only in Model 2).

Table 6

Median values of the complete set of protected polygons for the five bio-physical covariates by designation category in Model 1

NR: Nature Reserve; NP: Nature Park; SCI: Site of Community Importance; SPA: Special Protection Area

\begin{tabular}{cccccc}
\hline PA category & $\begin{array}{c}\text { Distance to cities } \\
(\mathrm{km})\end{array}$ & Altitude $(\mathrm{m})$ & $\begin{array}{c}\text { Slope } \\
(\text { degrees })\end{array}$ & $\begin{array}{c}\text { Initial artificial cover } \\
(\%)\end{array}$ & $\begin{array}{c}\text { Initial treeless cover } \\
(\%)\end{array}$ \\
\hline NR & 59.45 & 363.00 & 1.50 & 0.00 & 18.63 \\
NP & 26.45 & 609.00 & 5.50 & 0.06 & 18.99 \\
SCI & 41.60 & 613.00 & 4.00 & 0.00 & 22.83 \\
SPA & 33.62 & 554.00 & 4.00 & 0.00 & 33.48 \\
\hline
\end{tabular}

\section{Discussion}

\subsection{PA effectiveness assessment}

PAs are an effective territorial policy to prevent LULC changes towards artificial covers in Spain. NRs are the most effective PA category to prevent land development, as foreseen given their high legal stringency and existence of management (Martínez-Fernández et al., 2015). NR was the only assessed category whose regulations completely forbid land development (Spanish Government, 1989; 2007). Accordingly, no development occurred in the NR network between 1987 and 2006, even though NRs were more environmentally prone to development (and partly covered more area) than their controls. Two additional factors most likely reduced their probability of becoming artificial: the small area covered by the NR network related to the other networks and NRs' location furthest away from main cities. Moreover, all Spanish NRs overlapped with other designation categories which may have confounded the sought category's effect. In other countries, Sims (2014) found that legally stringent reserves in Thailand were more effective at preventing forest loss and fragmentation than more legally lenient national parks, though management effort was not assessed and could have also been greater in reserves. Similarly, Linardi et al. (2013) and Terra et al. (2014) found that legal stringency reduced negative LULC changes for biodiversity in Brazil's Atlantic forests compared to multiple-use regulations, although intense social pressure and inadequate management and governance limited their full effectiveness. Indirect effectiveness of PAs' legal stringency was also suggested for a global sample of PAs through isolation metrics
(Seiferling et al., 2012). In a worldwide review from 22 countries, Nagendra (2008) found no significant differences in rates of land cover change between legally stringent IUCN categories I-III, and more legally lenient categories IV-VI. However, NRs were scarce in the sample, specific results by category were not analysed and fine scale contextual and managerial factors were not taken into account.

Contrary to the extraordinary Spanish NR network performance, NRs' proximal buffers generally experienced the greatest development values of all control categories. This is consistent with high land development data around PAs in similar Wilderness Areas in the United States and in developing countries, which might indicate higher residential preference for well-preserved landscapes and/or increased socioeconomic opportunities near PAs, respectively (Wittemyer et al., 2008; Radeloff et al., 2010). The complete set of NPs was the second most effective PA network to prevent land development, even though they were also more prone to development than their controls. However, exclusive NP legislation provides little protection against land development even though NPs are zoned and afforded active management in Spain (Múgica et al., 2014). NPs are the nearest PA category to main cities and some of their management zones allow artificial developments (e.g. zones of regulated urban planning), which might have affected land development in some NPs' zones unaffected by other regulations.

Natura 2000 SPAs were the least effective PA category, with the greatest development values among the assessed PA categories and similar or even greater development than their controls. Proper explanation of those results is challenging, as SPA regulations (EEC, 1979 ; 1992) impose similar restrictions on the degradation of wild bird habitats as the Habitats Directive does for 
other taxa in SCIs (EEC, 1992) or regional regulations do for NPs [54, 44]. SPAs' relatively negative development values probably result from a combination of factors that increased this network's vulnerability to land development: SPAs have been unzoned, unmanaged and subject to relatively lenient legal implementation for a long time. They also covered a large area by 2000 , which probably made it difficult for civil organisations to inform legal developments or denounce illegal developments in over 8,000 municipalities across Spain. Finally, they had the greatest initial proportion of treeless covers, which facilitates land development and reduces the probability that they overlap with other potentially effective and widespread territorial regulations such as public utility forests.

Our results largely agree with those by (MartínezFernández et al., 2015) who found better performance against land development by nationally designated PAs than by Natura 2000 sites (using aggregated categories) and smaller PALCI but greater ALCI in Spanish Natura 2000 sites than in control areas over the same period. However, the positive results shown here for SCIs proof that these Natura 2000 Pas (EEC, 1992) are an effective territorial policy to conserve soil and natural ecosystems in Spain and that SPAs and SCIs behave differently regarding land development and should thus be analysed separately in LULC change assessments. Moreover, Spanish SCIs were, on average, the youngest PA network analysed here, with a mean age of seven years in $2006\left(t_{2}\right)$. They were designated, on average, over eleven years after their corresponding CLC-1990 scenes, which made that some of them were unprotected for a longer time than they were protected for the time length of this study. Therefore, the effectiveness of the Spanish SCI network is likely underestimated, as some of the observed development in that network has most likely occurred before those areas were given legal protection with a higher probability than in the other PA networks.

The proportion of artificial LULCs inside and around Spanish PAs in 2006 was still very low which suggests that derived pressures of land development such as PA fragmentation and isolation were not yet worrisome at that date, though values for some PAs on the coast or around big cities were most likely higher and deserve attention (Delgado 2008; Mallarach 2008; Rodríguez-Rodríguez and Martínez-Vega, 2013; García and de la Cruz, 2016). Additionally, new artificial uses around Spanish PAs tend to concentrate further than $1 \mathrm{~km}$ from the PA's boundary. This is a positive finding that further suggests that isolation was not a main conservation problem for the bulk of Spanish PAs in the considered period. However, the substantial increase of new artificial LULCs inside and around PAs should make territorial planners and EIA officers aware of their territorial implications for environmental sustainability (Radeloff et al., 2010) to carefully inform, condition or deny future development in those areas. Additionally, given the irreversibility of most LULC changes analysed here, the fact that all PA and buffer networks except NRs' increased their artificial covers in the assessed period should make territorial planners and decision-makers envisage new development options that imply no-net loss of natural and semi-natural habitats sustaining biodiversity and ecosystem services inside PAs and minimal such loss in surrounding habitats, as international policy requires (EC, 2011). Actually, the increase in land development values for some PA networks (e.g. SPAs; non-overlapping NPs) reveal environmentally unsustainable territorial development trends that should be stopped and, if possible, reverted.

Legal protection of PAs, by itself, prevents land development in Spain. These results are especially encouraging given that authorisations for land development are foreseen in most PA regulations, especially in multiple-use PA regulations, under certain circumstances such as development projects of overriding public interest and subject to EIA procedures (eec, 1992; Spanish Government, 2007). Besides, irregularities have occurred across the country as a result of ignoring or misinterpreting legal provisions, leading to illegal development in PAs (European Court, 2011). Legal and illegal LULC change processes have caused increased development inside Spanish PAs, chiefly in multiple-use PAs (Spanish Supreme Court, 2016; RodríguezRodríguez and Martínez-Vega in press), but also in reserves (Hernández-Calvento et al., 2003; RodríguezRodríguez and Martínez-Vega, 2013). This result adds to studies that showed the effectiveness of legally designated PAs at preventing land development in Spain (MartínezFernández et al., 2015; Rodríguez-Rodríguez and Martínez-Vega in press) and in tropical areas (DeFries et al., 2005; Joppa et al., 2008) and contrasts with common theoretical assumptions that minimise or deny the protective effect of legislation in PAs (Hockings et al., 2006; Dudley 2008). Pejoratively named 'paper parks' are actually likely to be ineffective to deliver conservation and socioeconomic benefits in places with weak or malfunctioning institutions, null political will or poor social conditions (Linardi et al., 2013; Terra et al., 2014) or at sea, where regulation breaches are difficult to detect and denounce (De Santo 2013). However, in areas with reasonably sound institutional and civil functioning regulations breaches are more detectable, indictable and punishable, which likely deters offenders and contributes to effective protection (Stern 2008; Ferraro and Hanauer, 2015).

Additional territorial legislation affecting freshwater areas and coastal areas increased protection inside PAs slightly. Moreover, freshwater, coastal and other PA regulations provided clear protection against land development to control areas. This result shows that other territorial regulations provide protection against land development in Spain and indicates that those regulations should be accounted for in LULC change studies in Spain, especially in control areas. The fact that Spanish coastal areas have been heavily affected by residential and infrastructural construction (Dias et al., 2013), that coastal regulations are frequently ignored in urban planning (Meilán 1996; Torres 2009) and that the vast majority of all 'exclusion' area to produce Model 1 corresponded to freshwater regulated areas, suggests that this protection 
effect in PPs was mostly due to freshwater regulations or other PA regulations. However, inadequate physical conditions for permanent constructions in river and lake banks (e.g. steep slopes; recurrent flooding) might have also naturally reduced development in those areas affected by freshwater legislation to some extent. Nevertheless, this result is encouraging given the high proportion of the Spanish territory under sectoral territorial legislation that restricts land development, such as public utility forests or cattle paths.

In contrast to what was expected (RodríguezRodríguez et al., 2016b; Rodríguez-Rodríguez and Martínez-Vega in press), the number of overlapping PA designations did not affect land development in Spanish PAs. Similarly, management did not reduce land development among multiple-use PAs, against previous claims (Hockings et al., 2006; Rodríguez-Rodríguez and Martínez-Vega in press). Land development can be considered an outer pressure to PAs and thus, largely independent from PA management. In Spain, urban planning is done and construction permits are awarded by local authorities, with the supervision of regional governments. Thus, land development seems to be more related to sectoral law (biodiversity, urban, industrial or transport legislation) than to PA management. Legislation regulating multiple-use PA categories (NPs or Natura 2000 sites) even allows some forms of land development within their borders after appropriate environmental assessments (EEC, 1992; Spanish Government, 2007). PA managers can do little more to counter this legal 'gap', which may allow necessary local socioeconomic development while compromising PA effectiveness measured by indicators such as the ones used here, than inform territorial plans and denounce irregularities that affect their areas. Civil organisations such as environmental NGOs can and often play the same 'watchdog' role, especially in unmanaged Pas (Racinska et al., 2015; WWF, 2017), which may further blur management's influence on land development.

\subsection{Methodological findings}

Spanish PAs are not always environmentally similar to their surroundings. Thus the common assumption that the areas surrounding PAs are environmentally similar or more similar to PAs than more distant areas cannot be taken for granted and should always be checked before it is stated (Spracklen et al., 2015; Rodríguez-Rodríguez and Martínez-Vega in press). What is more, even different PAs and PA networks can be bio-physically distinct (Araújo et al., 2011; Martínez-Fernández et al., 2015). In contrast, the suggestion that PAs are usually designated in areas that are naturally more protected against negative LULC changes like development (Mas 2005; Andam et al., 2008; Gaston et al., 2008; Spracklen et al., 2015) seems to be generally correct in the Spanish case.

The simple, spatial-statistical covariate control technique used did not result consistent to make all cases and control more environmentally similar. Methodological improvements with regard to prior studies (RodríguezRodríguez and Martínez-Vega in press) such as preliminary selection of uncorrelated significant covariates, exclusion of entire individual buffers according to average covariate values, or reclassification of continuous covariate values in ranks have not been sufficient to fine-tune the technique. It is possible that excluding case and control areas for every significant covariate sequentially may 'unbalance' previously balanced values for the preceding covariate(s). The fact that environmental dissimilarity increases as the number of PPs and amount of analysed area rises (NPs < SPAs < SCIs) suggests greater difficulty at environmentally balancing heterogeneous landscapes across broad areas than individual PAs or spatially restricted areas (Mas 2005). To solve the possible issue of sequential unrepresentative covariate area exclusion, we tried excluding 'unrepresentative' area for the five bio-physical covariates at once but the amount of spatially coincident 'unrepresentative area' represented $0 \%$ of all the PA area and just $0.03 \%$ and $0.04 \%$ of $1 \mathrm{~km}$ and $5 \mathrm{~km}$-buffer area, respectively, so results were foreseen to be very similar to Model 1.

\subsection{Methodological considerations}

This study has some important methodological advantages that increased its accurateness related to earlier studies. Firstly, it applied a more accurate BACI design by selecting only PAs that had been designated after their corresponding baseline $\left(\mathrm{t}_{1}\right)$ CLC-1990 data and at least 3 years before their comparison time point $\left(\mathrm{t}_{2}\right)$, to allow PAs enough time to show some effectiveness. Secondly, the PP approach used made it possible to discriminate the single effect of different 'pure' PA categories as well as the cumulative effect of multiple designation categories on land development. Thirdly, accounting for additional territorial legislation permitted to partially control (as not all sectoral digital layers could be retrieved) the effect of that relevant and often ignored confounding variable. Fourthly, consideration of bio-physical factors that are likely to influence land development, though did not render the expected results for Model 2, served to test and verify some methodological hypotheses. Fifthly, using two control areas at increasing distances also allowed testing some methodological and theoretical hypotheses. Finally, the development and comparison of three increasingly complex and theoretically more valid models increased reliability in coincident results.

There are, however, some methodological comments to make to the data used. Firstly, issues linked to CLC data completeness, accurate LULC identification and broad resolution have been frequently mentioned (Catalá et al., 2008; Díaz-Pacheco and Gutiérrez, 2013; MartínezFernández et al., 2015). Secondly, the reliability of the CLC data by the Spanish official provider (National Geographic Institute) is improvable. Even though the selfcompletion of missing CLC-2006 artificial LULCs with CLC-1990 ones was not likely to greatly affect our results, some overestimation of land development figures in 2006 is expected. Thirdly, the fact that additional digital territorial legislation could not be included in Models 1 
and 2 (e.g. cattle paths or public utility forests) has most likely reduced result accuracy, chiefly in control areas.

\section{Conclusions}

Spanish PAs are an effective territorial policy to prevent land development in a country that has experienced recent fast artificial sprawl across its landscape (Jiménez 2012; Alfonso et al., 2016). Except NRs, PAs did not stop land development but reduced it compared to control areas. The PP sets and categories that resulted most effective to prevent land development were NRs, complete NPs and non-overlapping SCIs, respectively. The high legal stringency, convenient location and small area covered by the NR network have likely determined its high effectiveness. The PA categories that were least effective were non-overlapping NPs and complete SPAs, respectively. Legal protection is effective to prevent land development in Spain. Unmanaged, multiple-use, single PA designations have been effective against land development, in contrast to common theoretical assumptions (Hockings et al., 2006; Dudley 2008). Active management does not seem to prevent land development in Spanish PAs, probably because land development processes are outside the scope of PA managers. The environmental similarity of cases and controls should always be checked before being assumed in comparative studies. Additional sectoral legislation should also be considered as it affects chiefly control areas. The methodology of this study improves the accurateness and reliability of some previous studies. However, a modification of the covariate control technique used here or an entirely new technique should be used to consistently make cases and controls biophysically more similar (if they are not originally), and comparisons more valid. Considering result inconsistencies and time and effort to produce Model 2, Model 1 should be considered the best fit-for -purpose model to assess land development in PAs in Spain. Prevention of natural LULC destruction is an essential measure of PA effectiveness (Gaston et al., 2008; Joppa et al., 2008). However, other important PA performance metrics such as species protection (Araújo et al., 2007; Gaston et al., 2006, 2008), adequate design (Joppa et al., 2008), fragmentation (Sims 2014), isolation (DeFries et al., 2005; Radeloff et al., 2010;Seiferling et al., 2012), human activities (Joppa et al., 2008), or forest fires should also be assessed in order to provide comprehensive PA conservation effectiveness assessments.

\section{Acknowledgments}

This paper recognises contributions through the 'sequence-determines-credit' approach. We would like to acknowledge Pilar Echavarría, from the IEGD-CSIC, for her GIS support. We would also like to thank José Manuel Rojo, from the CCHS-CSIC, for his statistical advice. DRR was funded for this study by the Spanish Ministry of
Economy, Industry and Competitiveness in the framework of the SOSTPARK project (CSO2014-54611-JIN).

\section{References}

Addison P. A global review of long-term Marine Protected Area monitoring programmes: The application of a good framework to marine biological monitoring. A report prepared for the Joint Nature Conservation Committee. Joint Nature Conservation Committee, 2011. Available from: http://jncc.defra.gov.uk/pdf/jncc455_Vol1_web.pdf

Alfonso C, Avellaner J, Estévez R, García A, Martínez J, Prieto F, Santamarta J. SOS16. Sostenibilidad en España 2016. Cumplimiento de los Objetivos de Desarrollo Sostenible de Naciones Unidas. Asociación Observatorio de la Sostenibilidad, 2016. Available from: http://www.observatoriosostenibilidad.com/documentos/S OS16_v23_PDF_final.pdf

Andam KS, Ferraro PJ, Pfaff A, Sánchez-Azofeifa GA, Robalino JA. Measuring the effectiveness of protected area networks in reducing deforestation. PNAS. 2008; 105(42): 16089-16094.

Araújo MB, Lobo JM, Moreno JC. The Effectiveness of Iberian Protected Areas in Conserving Terrestrial Biodiversity. Conservation Biology. 2007; 21(6): 1423 1432.

Araújo MB, Alagador D, Cabeza M, Nogués-Bravo D, Thuiller W. Climate change threatens European conservation areas. Ecology Letters. 2011; 14: 484-492.

Atauri JA, Múgica M, Gómez-Limón J, de Lucio JV. Procedimiento para la asignación de las categorías internacionales de manejo de áreas protegidas de la UICN. Madrid: Ed. Fundación Fernando González Bernáldez, 2008.

Carranza T, Manica A, Kapos V, Balmford A. Mismatches between conservation outcomes and management evaluation in protected areas: A case study in the Brazilian Cerrado. Biological Conservation. 2014; 173: 10-16.

Catalá Mateo R, Bosque Sendra J, Plata Rocha W. Análisis de posibles errores en la base de datos CORINE Land Cover (1990-2000) en la Comunidad de Madrid. Estudios Geográficos. 2008; 49: 81-104.

Davis McK, Naumann S, McFarland K, Graf A, Evans D. Literature review: The ecological effectiveness of the Natura 2000 Network. Technical paper $N^{\circ}$ 5/2014. Paris: European Topic Centre on Biological Diversity European Environment Agency, 2014.

De Santo EM. Missing marine protected area (MPA) targets: how the push for quantity over quality undermines sustainability and social justice. Journal of Environmental Management. 2013; 124: 137-146. 
DeFries R, Hansen A, Newton AC, Hansen MC. Increasing isolation of protected areas in tropical forests over the past twenty years. Ecological Applications. 2005; 15(1): 19-26.

Delgado C. Urbanización sin fronteras. El acoso urbanístico a los espacios naturales protegidos. Boletín de la Asociación de Geógrafos Españoles. 2008; 47: 271-310

Dias JA, Cearreta A, Isla FI, Mahiques MM. Anthropogenic impacts on Iberoamerican coastal areas: Historical processes, present challenges, and consequences for coastal zone management. Ocean \& Coastal Management. 2013; 77: 80-88

Díaz-Pacheco J, Gutiérrez J. Exploring the limitations of CORINE land cover for monitoring urban land-use dynamics in metropolitan areas. Journal of Land Use Science. 2014; 9(3): 243-259.

Dudley N. (ed.) 2008. Guidelines for Applying Protected Area Management Categories. Gland: IUCN, 2008.

EC, European Commission. Communication from the Commission to the European Parliament, the Council, the Economic and Social Committee and the Committee of the Regions Our life insurance, our natural capital: an EU biodiversity strategy to 2020. 2011. Available from: http://eur-lex.europa.eu/legal-

content/EN/TXT/HTML/?uri=CELEX:52011DC0244\&fro $\underline{\mathrm{m}=\mathrm{EN}}$

European Communities. Managing Natura 2000 Sites. The provisions of Article 6 of the 'Habitats' Directive 92/43/EEC. Luxembourg: Office for Official Publications of the European Communities, 2000. Available from: http://ec.europa.eu/environment/nature/natura2000/manag ement/docs/art6/provision_of_art6_en.pdf

European Court. European Court Reports 2011. ECLI:EU:C:2011:835. Judgment of the Court (Fifth Chamber) of 15 December 2011 - Commission v Spain (Case C-560/08). 2011. Available from: http://curia.europa.eu/juris/celex.jsf?celex $=62008 \mathrm{CJ} 0560$ \&lang1=en\&type $=$ TXT\&ancre $=$

EEA, European Environment Agency. Landscape fragmentation in Europe. A joint EEA-FOEN Report. EEA report No 2/2011. Luxembourg: Publications Office of the European Union, 2011.

EEA, European Environment Agency. 2015a. The European environment - state and outlook 2015. Luxembourg: Publications Office of the European Union. Available from: http://www.eea.europa.eu/soer

EEA, European Environment Agency. Data and maps. Datasets. Natura 2000 data - the European network of protected sites. 2015 . Available from: http://www.eea.europa.eu/data-and-maps/data/natura-6

EEC, European Economic Community. Council Directive 79/409/EEC of 2 April 1979 on the conservation of wild birds. Official Journal L. 1979; 103: 0001-0018. Available from: $\quad \mathrm{http} / / /$ eur-lex.europa.eu/legalcontent/ES/TXT/?uri=URISERV\%3Al28046

EEC, European Economic Community. Council Directive 92/43/EEC of 21 May 1992 on the conservation of natural habitats and of wild fauna and flora. Official Journal L. 1992; 206: 0007 - 0050. Available from: http://eurlex.europa.eu/legalcontent/en/TXT/?uri=CELEX\%3A31992L0043

Fernández-Tabales F, Cruz E. Análisis territorial del crecimiento y crisis del sector de la construcción en España y la Comunidad Autónoma de Andalucía. Eure. 2013; 39(116): 5-37.

Ferraro PJ, Hanauer MM. Through what mechanisms do protected areas affect environmental and social outcomes? Philosophical Transactions B. 2015; 370: 20140267.

Fiorini L, Zullo F, Romano B. Urban development of the coastal system of the Italian largest islands: Sicily and Sardinia. Ocean \& Coastal Management, 2017; 143: 184 194.

Foster NL, Sciberras M, Jackson EL, Ponge B, Toison V, Carrier S, et al. Assessing the Ecological Coherence of the Channel MPA Network. Report prepared by the Marine Institute for the Protected Area Network Across the Channel Ecosystem (PANACHE) project. INTERREG programme France (Channel) England funded Project. 2014. Available from: http://www.panache.eu.com/upload/iedit/12/pj/2147 5703 _WP1ENPANACHE_WP1_Action_1.pdf

García M. The breakdown of the Spanish urban growth model: social and territorial effects of the global crisis. International Journal of Urban and Regional Research. 2010; 34: 967-980.

García B, de la Cruz S. Efectos del planeamiento municipal en la protección de la Red Natura 2000: Andalucía, Castilla-La Mancha, Extremadura y Madrid. Ciudad y Territorio: Estudios Territoriales. 2016; 190: 595-608.

Gaston KJ, Charman K, Jackson SF, Armsworth PR, Bonn A, Briers RA, et al. The ecological effectiveness of protected areas: The United Kingdom. Biological Conservation, 2006; 132: 76-87.

Gaston KJ, Jackson SF, Cantú-Salazar L, Cruz-Piñón G. The ecological performance of protected areas. Annual Review of Ecology, Evolution and Systematics. 2008; 39: 93-113. 
Hernández-Calvento L, Ruiz P, Alonso I, Alcántara J, Pérez-Chacón E, Suárez C. Transformaciones inducidas por el desarrollo turístico en el campo de dunas de Maspalomas (Gran Canaria, Islas Canarias), GeoFocus. 2003; 3: 127-142.

Hockings M, Stolton S, Leverington F, Dudley N, Courrau J. Evaluating Effectiveness: A framework for assessing management effectiveness of protected areas. $2^{\text {nd }}$ Edition. Gland and Cambridge: IUCN, 2006.

IGN, Instituto Geográfico Nacional. Centro de descargas. Centro Nacional de Información geográfica. Catálogo de productos. Base Cartográfica Nacional 1:500.000. BCN 1:500. Versión 2.3. 2012. Available from: http://centrodedescargas.cnig.es/CentroDescargas/catalogo .do;jsessionid=76B6BFF30E1DBAB4B3993F1F95C2895 4\#selectedSerie

Iojă CI, Pătroescu M, Rozylowicz L, Popescu VD, Vergheleţ M, Zotta MI, Felciuc M. The efficacy of Romania's protected areas network in conserving biodiversity. Biological Conservation. 2010; 143(11): 2468-2476.

Jiménez LM (dir.) Sostenibilidad en España 2009. Informe de primavera. Alcalá de Henares: Observatorio de la Sostenibilidad en España, 2009.

Jiménez LM (dir.). Sostenibilidad en España 2010. Alcalá de Henares: Observatorio de la Sostenibilidad en España, 2010 .

Jiménez LM (dir.). Sostenibilidad en España 2012. Capítulo especial energía sostenible para todos (2012 Año Internacional de la Energía). Madrid: Ministerio de Agricultura, Alimentación y Medio Ambiente, 2012.

Joppa LN, Loarie SR, Pimm, SL. On the protection of "protected areas". PNAS. 2008; 105(18): 6673-6678.

Piekielek NB, Hansen AJ. Extent of fragmentation of coarse-scale habitats in and around U.S. National Parks. Biological Conservation. 2012; 155: 13-22.

Linardi AC, Pavao T, dos Santos RF. The conservation success over time: Evaluating the land use and land cover change in a protected area under a long re-categorization process. Land Use Policy. 2013; 30: 177-185.

López-Rodríguez F, Rosado D. Management effectiveness evaluation in protected areas of southern Ecuador. Journal of Environmental Management. 2017; 190: 45-52.

MAGRAMA, Ministerio de Agricultura, Alimentación y Medio Ambiente. Cartografía y SIG. Infraestructura de Datos Espaciales-IDE. Descargas. Biodiversidad. 2015. Available from:
Mallarach JM (coord.). Protegits de fet o de dret? Primera avaluació del sistema d'espais naturals protegits de Catalunya. Institució Catalana d'Història Natural, 2008. Available from: http://ichn.iec.cat/Avaluacio Espais.htm

Mallinis G, Koutsias N, Arianoutsou M. Monitoring land use/land cover transformations from 1945 to 2007 in two peri-urban mountainous areas of Athens metropolitan area, Greece. Science of the Total Environment, 2014; 490: 262-278.

Martínez-Fernández J, Ruiz-Benito P, Zavala MA. Recent land cover changes in Spain across biogeographical regions and protection levels: Implications for conservation policies. Land Use Policy. 2015; 44: 62-75.

Mas JF. Assessing Protected Areas effectiveness using surrounding (buffer) areas environmentally similar to the target area. Environmental Monitoring and Assessment. 2005; 105: 69-80.

McDonald RI, Kareiva, P, Forman RTT. The implications of current and future urbanization for global protected areas and biodiversity conservation. Biological Conservation. 2008; 141:1695-1703.

McKinney ML. Urbanization, biodiversity and conservation. BioScience. 2002; 52(10): 883-890.

Jiménez L, Prieto F, Riechmann J, Gómez A. (coord.). Sostenibilidad en España 2005. Informe de primavera. Alcalá de Henares: Observatorio de la Sostenibilidad en España, 2005.

Médail F, Quézel P. Biodiversity Hotspots in the Mediterranean Basin: Setting global conservation priorities. Conservation Biology. 1999; 13(6): 1510-1513.

Meilán JL. El dominio público natural y la legislación de costas. Revista de Administración Pública. 1996; 139: 7. 47.

Múgica M, Martínez C, Atauri JA, Gómez-Limón J, Puertas J, García D. EUROPARC-España. Anuario 2013 del estado de las áreas protegidas en España. Madrid: Fundación Fernando González Bernáldez, 2014.

Nagendra H. Do parks work? Impact of protected areas on land cover clearing. AMBIO. 2008; 37(5): 330-337.

Oudin L, Andréassian V, Perrin C, Michel C, le moine N. Spatial proximity, physical similarity, regression and ungaged catchments: A comparison of regionalization approaches based on 913 French catchments. Water Resources Research. 2008; 44(3): W03413, doi:10.1029/2007WR006240

Pfeifer M, Burgess ND, Swetnam RD, Platts PJ, Willcock S, Marchant R. Protected areas: Mixed success in 
conserving east Africa's evergreen forests. PLoS ONE. 2012; 7(6): e39337. doi:10.1371/journal.pone.0039337.

Pressey RL, Cabeza M, Watts ME, Cowling RM, Wilson KA. Conservation planning in a changing world. Trends in Ecology and Evolution. 2007; 22(11): 583-592.

Racinska I, Barratt L, Marouli C. LIFE and Land Stewardship. Current status, challenges and opportunities. Report to the European Commission. 2015. Available from:

http://ec.europa.eu/environment/life/publications/lifepubli cations/generalpublications/documents/life_land_stewards hip.pdf

Radeloff VC, Stewart SI, Hawbaker TJ, Gimmi U, Pidgeon AM, Flather $\mathrm{CH}$, et al. Housing growth in and near United States protected areas limits their conservation value. PNAS. 2010; 107(2): 940-945.

Rodríguez-Rodríguez D. Los espacios naturales protegidos de la Comunidad de Madrid. Principales amenazas para su conservación. Madrid: Editorial Complutense, 2008.

Rodríguez-Rodríguez D, Martínez-Vega J. Evaluación de la eficacia de las áreas protegidas. El Sistema de Evaluación Integrada de Áreas Protegidas (SEIAP). Resultados de la primera evaluación integrada de los espacios naturales protegidos de la Comunidad de Madrid. Madrid: Fundación BBVA, 2013.

Rodríguez-Rodríguez D, Martínez-Vega J, Tempesta M, Otero-Villanueva MM. Limited uptake of protected areas evaluation systems among managers and decision-makers in Spain and the Mediterranean Sea. Environmental Conservation. 2015; 42(3): 237-254.

Rodríguez-Rodríguez D, Rodríguez J, Blanco JM, Abdul Malak D. Marine protected area design patterns in the Mediterranean Sea: Implications for conservation. Marine Pollution Bulletin. 2016 ${ }_{\mathrm{a}}$; 110(1): 335-342.

Rodríguez-Rodríguez D, Rodríguez J, Abdul Malak D. Development and testing of a new framework for rapidly assessing legal and managerial protection afforded by marine protected areas: Mediterranean Sea case study. Journal of Environmental Management. 2016 ; 167: 2937.

Rodríguez-Rodríguez D, Martínez-Vega J. Effect of legal protection and management on the environmental performance of protected areas: A Spanish case study. Land Use Policy. In press.

Schreckenberg K, Camargo I, Withnall K, Corrigan C, Franks P, Roe D, et al. Social assessment of conservation initiatives. A review of rapid methodologies. London: IIED. Natural Resource Issues No. 22, 2010.
Seiferling IS, Proulx R, Peres-Neto PR, Fahrig L, Messier C. Measuring protected-area isolation and correlations of isolation with land-use intensity and protection status. Conservation Biology. 2012; 26(4): 610-618.

Seto KC, Guneralp B, Hutyra LR. Global forecasts of urban expansion to 2030 and direct impacts on biodiversity and carbon pools. PNAS. 2012; 109(40): 16083-16088.

Sims KRE. Do protected areas reduce forest fragmentation? A microlandscapes approach. Environmental and Resource Economics. 2014; 58: 303333.

Smith EP. BACI design. In El-Shaarawi AH, Piegorsch WW (eds.). Encyclopedia of Environmetrics, Vol. 1; pp: 141-148. Chichester: John Wiley \& Sons, 2002.

IGN, Instituto Geográfico Nacional. Centro Nacional de Información Geográfica. Centro de Descargas. Catálogo de productos. Corine Land Cover. 2016. Available from: http://centrodedescargas.cnig.es/CentroDescargas/buscar.d $\underline{\mathrm{o}}$

Smith P, House JI, Bustamante M, Sobocka J, Harper R, Pan G, et al. Global change pressures on soils from land use and management. Global Change Biology. 2016; 22: 1008-1028.

Spanish Government. Ley 29/1985, de 2 de agosto, de Aguas. Boletín Oficial del Estado. 1985; 189: 25123 25135. Available from: https://www.boe.es/boe/dias/1985/08/08/pdfs/A2512325135.pdf

Spanish Government. Ley 22/1988, de 28 de Julio, de Costas. Boletín Oficial del Estado. 1988; 181: 23386 23401. Available from: https://www.boe.es/boe/dias/1988/07/29/pdfs/A2338623401.pdf

Spanish Government. Ley 4/1989, de 27 de marzo, de Conservación de los Espacios Naturales y de la Flora y Fauna Silvestres. Boletín Oficial del Estado. 1989; 74: 8262-8269.

Spanish Government. Real Decreto Legislativo 1/2001, de 20 de julio, por el que se aprueba el texto refundido de la Ley de Aguas. Boletín Oficial del Estado. 2001; 176: 26791-26817. Available from: https://www.boe.es/boe/dias/2001/07/24/pdfs/A2679126817.pdf

Spanish Government. Ley 42/2007, de 13 de diciembre, del Patrimonio Natural y de la Biodiversidad. Boletín Oficial del Estado. 2007; 299: 51275-51327. Available from:

https://www.boe.es/boe/dias/2007/12/14/pdfs/A5127551327.pdf 
Spanish Government. Ley 30/2014, de 3 de diciembre, de Parques Nacionales. Boletín Oficial del Estado. 2014; 293 : 99762-99792. Available from: https://www.boe.es/boe/dias/2014/12/04/pdfs/BOE-A2014-12588.pdf

Spanish Supreme Court. Sentencia No 272/2016. Plan de Ordenación de los Recursos Naturales. Parque Natural Cabo de Gata-Níjar. Zonificación. Sentencia firme anterior. Principio de seguridad jurídica. Contradicción de sentencias. 2016. Available from: http://www.poderjudicial.es/stfls/TRIBUNAL\%20SUPRE MO/DOCUMENTOS\%20DE\%20INTER\%C3\%89S/TSC ontencioso\%205\%20Madrid\%2010.02.16\%20(194714).pdf

Spracklen BD, Kalamandeen M, Galbraith D, Gloor E, Spracklen DV. A global analysis of deforestation in moist tropical forest protected areas. PLoS ONE. 2015; 10(12): e0143886. doi:10.1371/journal.pone.0143886

Stern MJ. Coercion, voluntary compliance and protest: the role of trust and legitimacy in combating local opposition to protected areas. Environmental Conservation. 2008; 35(3): 200-210.

Stortini CH, Shackell NL, O'Dor RK. A decision-support tool to facilitate discussion of no-take boundaries for Marine Protected Areas during stakeholder consultation processes. Journal for Nature Conservation. 2015; 23: 4552.

Terra TN, dos Santos RF, Cortijo D. Land use changes in protected areas and their future: The legal effectiveness of landscape protection. Land Use Policy. 2014; 38: 378-387.
Torres A, Jaeger JAG, Alonso JC. Assessing large-scale wildlife responses to human infrastructure development. PNAS. 2016; 113(30): 8472-8477.

Torres FJ. La ocupación del dominio público marítimoterrestre en España. Investigaciones Geográficas. 2009; 50: 63-91.

Venter O, Fuller RA, Segan DB, Carwardine J, Brooks T, Butchart SHM, et al. Targeting global protected area expansion for imperiled biodiversity. PLoS Biology, 2014; 12(6), e1001891. doi.org/10.1371/journal.pbio.1001891

Williams PH, Humphries C, Araújo MB, Lampinen R, Hagemeijer W, Gasc JP, Mitchell-Jones T. Endemism and important areas for representing European biodiversity: a preliminary exploration of atlas data for plants and terrestrial vertebrates. Belgian Journal of Entomology. 2000; 2: 21-46.

Wittemyer G, Elsen P, Bean WT, Coleman A, Burton O, Brashares JS. Accelerated human population growth at protected area edges. Science. 2008; 321: 123-126

WWF, World Wildlife Fund. Living Planet Report 2016. Risk and resilience in a new era. Gland: WWF International, 2016.

WWF, World Wildlife Fund. Preventing Paper Parks: How to make the EU laws work. WWF-EU Report 2017. 2017. Available from: http://wwf.panda.org/about_our_earth/all_publications/?29 1910/Preventing-Paper-

Parks\&dm_i=2GI3,10RBI,4TLQLQ,2ZEEG,1 